\title{
Chelating agent: The health protector of researchers in lead halide
}

\author{
perovskite laboratory \\ Yu-Hao Deng ${ }^{1 *}$ \\ ${ }^{1}$ Academy for Advanced Interdisciplinary Studies, Peking University, Beijing, China \\ *Correspondence should be addressed to yuhaodeng@pku.edu.cn
}

\begin{abstract}
Lead halide perovskites have achieved substantial success in various optoelectronic devices owing to their remarkable physical properties. However, lead $(\mathrm{Pb})$ as a heavy metal, longlasting toxic to the body has become a health hazard for researchers. How to completely remove the residual lead in the laboratory and prevent lead from entering the human body have always been an important topic in laboratory safety. Here we develop an operable method to treat lead sources with low-cost and eco-friendly chelating agent (EDTA-2Na), which can reduce the concentration of free lead ions to $10^{-11} \mathrm{ppm}$ theoretically. Moreover, experiments have demonstrated that the EDTA-2Na possess a strong ability on the removal of lead ions from the lab surface, gloves and lab coats. This approach paves the way to protect the health of researchers in lead halide perovskite laboratory.
\end{abstract}

Key words: Laboratory safety, perovskite, lead, toxicity, chelating agent, EDTA-2Na

\section{Introduction}

Lead halide perovskites, which can be synthesized via low-cost solution-based methods, have emerged as a new generation of semiconductor materials with extraordinary performance in various optoelectronic devices including solar cells, light-emitting diodes, photodetectors and lasers [1-6]. However, the presence of heavy metal lead $(\mathrm{Pb})$ in these materials, has caused serious concerns due to the high perceived toxicity. Exposure to lead will induce brain damage, kidney damage, bone damage, heart disease, urogenital diseases and gastrointestinal diseases ${ }^{[7-10]}$. More seriously, the absorption of lead by the human body is cumulative and difficult to expel, and the damage is irreversible [11]. The Institute for Health Metrics and Evaluation (IHME) estimated that in 2017, lead exposure resulted in 1,060,000 deaths and $24,400,000$ 
years of healthy life lost (disability-adjusted life years (DALYs)) worldwide due to long-term effects on health [12]. Some established instructions to avoid exposure to lead have been run in perovskite research laboratories, such as wearing lab coats, gloves and masks, removing used gloves safely, operating in glovebox, and supplementing protein [13-15]. But none of these methods can completely remove the residual lead in the laboratory and avoid absorption of lead by the human body.

\section{Results and Discussion}

Herein, a way towards completely removing lead ions from the laboratory has been proposed. EDTA-2Na, a cheap, non-toxic and environment-friendly chelating agent, is used to react with lead ions. EDTA-2Na has extremely strong chelating ability to lead ion $\left(\mathrm{Pb}^{2+}\right)$, and the stability constant $\left(\boldsymbol{K}_{\mathrm{Sc}}=\boldsymbol{c}_{\mathrm{EDTA}-\mathrm{Pb}} / \boldsymbol{c}_{\mathrm{Pb}}{ }^{2+} \cdot \boldsymbol{c}_{\mathrm{EDTA}-2 \mathrm{Na}}\right)$ is up to $10^{18}[16]$. Theoretically, the concentration of free lead ions in laboratory can be reduced to $10^{-11} \mathrm{ppm}$ by EDTA-2Na. The complexation ability between EDTA-2Na and lead ion is far more than that of hemoglobin and lead ion. Therefore, lead complexed by EDTA-2Na cannot react with hemoglobin and will not accumulate in human body. The chemical reaction process is shown in Fig. 1. In particular, EDTA-2Na has been industrially produced and widely used in the fields of heavy metal detoxification, food additives, ecological restoration and photo fixing solution [17-20].

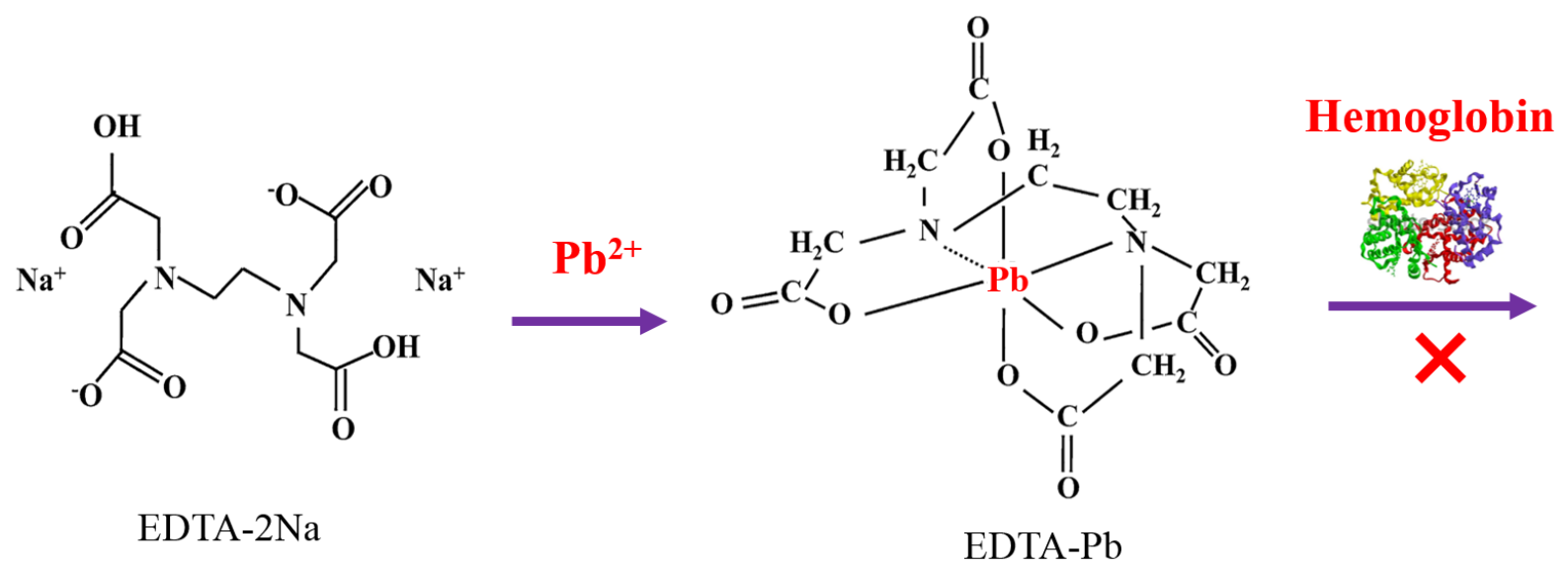

Fig. 1. Schematic diagram of lead removal by EDTA-2Na. EDTA-2Na will react with $\mathrm{Pb}^{2+}$ to produce EDTA-Pb, but due to the large high stability constant $\left(\boldsymbol{K}_{\mathrm{sc}}=10^{18}\right)$ of EDTA-Pb, EDTA-Pb will not react with hemoglobin.

Fig. 2 shows the practical ability on removing lead ions from lab surface. Phenolic resin sheets were selected as they have been widely used in laboratory decoration materials ${ }^{[21]}$. Sheets were impregnated in lead bromide $\left(\mathrm{PbBr}_{2}\right)$ solution $(0.1 \mathrm{M}, \mathrm{DMF})$ and taken out to dry 
naturally. The surfaces of sheets were scrubbed by dry cleaning, water cleaning and EDTA$2 \mathrm{Na}$ aqueous solution $\left(0.1 \mathrm{M}, \mathrm{H}_{2} \mathrm{O}\right)$ cleaning once and twice respectively. Lab surface testing for lead can be carried out using dithizone $\left(\mathrm{C}_{13} \mathrm{H}_{12} \mathrm{~N}_{4} \mathrm{~S}\right)$ colouration (4mM, Ethanol), and this is practiced by national standard with a detection limit of 1ppm [22, 23]. The higher concentration of lead ion, the deeper red color appears on the surface. As shown in Fig. 2, dry cleaning has a limited ability to remove the residual lead on the lab surface. Water cleaning has a better result, but it is still difficult to completely remove lead ions. After $1^{\text {st }}$ cleaned by EDTA$2 \mathrm{Na}$, residual lead ions on the surface have been completely removed. This indicates that EDTA-2Na has a strong ability to remove lead ions from the lab surface.

$$
\text { Dry cleaning Water cleaning EDTA-2Na cleaning }
$$

Before cleaning
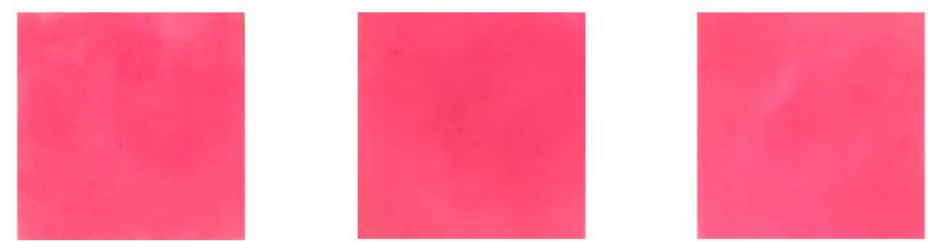

After $1^{\text {st }}$ cleaning
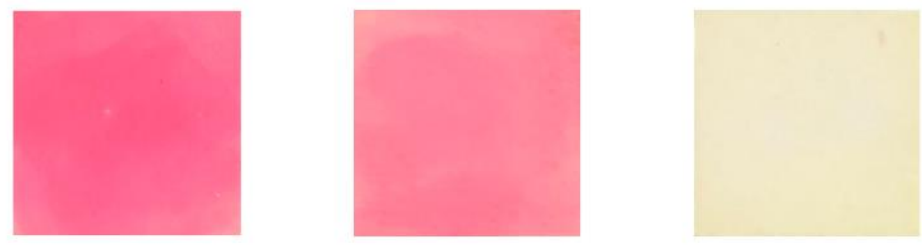

After $2^{\text {nd }}$ cleaning
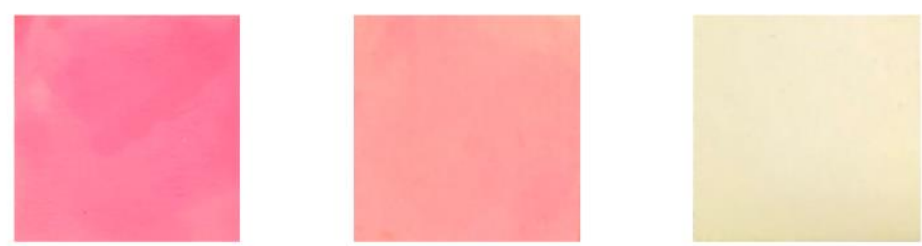

Fig. 2. Tests of the ability to remove lead ions from lab surface. Water cleaning has a better ability than dry cleaning, but the $\mathrm{Pb}^{2+}$ still has the obvious residual. Only EDTA-2Na solution can completely remove $\mathrm{Pb}^{2+}$ from the lab surface.

But that of lab surface, gloves and lab coats also are main sources of lead exposure for researchers. Then, we compared the removal ability of lead ions by water and EDTA-2Na solution $\left(0.1 \mathrm{M}, \mathrm{H}_{2} \mathrm{O}\right)$ washing. As shown in Fig. 3, water washing can remove most of lead ions from gloves but not absolutely, but not effective for removing lead ions from lab coats. For comparison, EDTA-2Na showed complete removal ability of lead ions from both gloves and lab coats. The surfaces appear yellow-brown due to the original color of dithizone solution. 


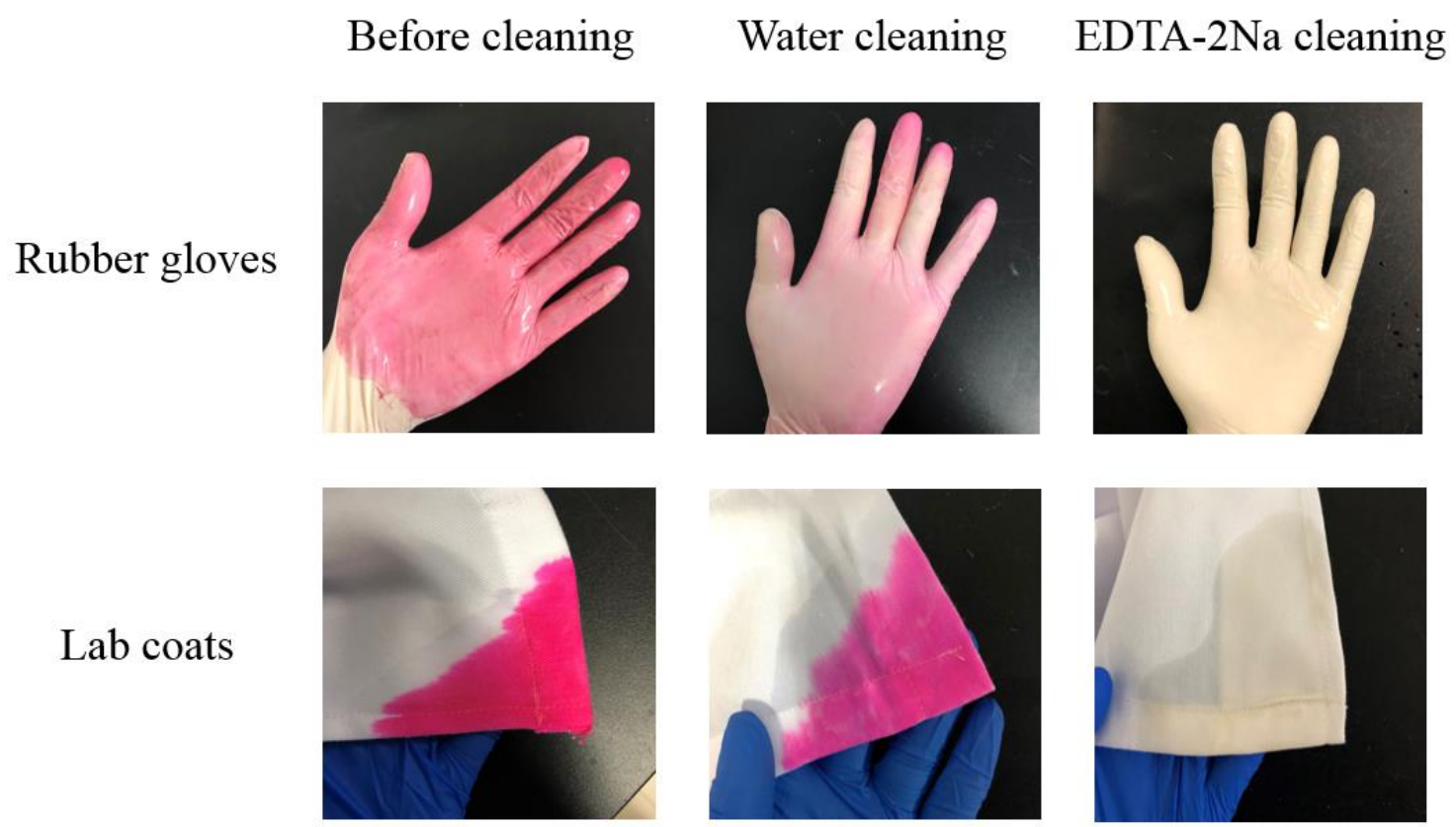

Fig. 3. Tests of the ability to remove lead ions from gloves and lab coats in laboratory. Similarly, water cleaning also has the limited ability to remove $\mathrm{Pb}^{2+}$ from gloves and lab coats. Only EDTA-2Na solution can completely remove $\mathrm{Pb}^{2+}$ from their surfaces.

\section{Conclusions}

In summary, this study shows that the treatment of lead sources with low-cost and ecofriendly chelating agent EDTA-2Na can completely remove lead ions from the laboratory. The complete removal of lead ions prevent lead from entering the human body and accumulating, protecting the health of researchers in lead halide perovskite laboratory. This method can not only be used for the laboratory safety of lead $(\mathrm{Pb})$ sources, but also cadmium $(\mathrm{Cd})$, mercury $(\mathrm{Hg})$ and other heavy metals (Table 1) [12, 24-30]. Owing to environmental concerns, subsequent processing of laboratory samples and reprocessing of perovskite solar cells can also refer to this approach $[11,31]$. 
Table 1. Summary of heavy metals that can be complexed by EDTA-2Na.

\begin{tabular}{|c|c|c|c|c|c|c|}
\hline $\begin{array}{c}\text { Sequence } \\
\text { number }\end{array}$ & $\begin{array}{l}\text { Chemical } \\
\text { element }\end{array}$ & $\begin{array}{c}\text { Stability } \\
\text { constant }\left(\boldsymbol{K}_{s c}\right)\end{array}$ & $\begin{array}{l}\text { Applied } \\
\text { materials }\end{array}$ & $\begin{array}{l}\text { Blood } \\
\text { limit } \\
\text { Level } \\
\text { (ppm) }\end{array}$ & Toxicity & Ref. \\
\hline 1 & $\mathrm{~Pb}^{2+}$ & $10^{18}$ & $\begin{array}{l}\text { PbS, PbSe, } \\
\text { Perovskite }\end{array}$ & 10 & $\begin{array}{l}\text { Brain, bone, } \\
\text { blood cells }\end{array}$ & 12 \\
\hline 2 & $\mathrm{Cd}^{2+}$ & $10^{16.5}$ & $\begin{array}{c}\mathrm{CdS}, \mathrm{CdSe}, \\
\mathrm{CdTe}\end{array}$ & 0.12 & $\begin{array}{c}\text { Kidney, bone, } \\
\text { lung }\end{array}$ & 24 \\
\hline 3 & $\mathrm{Hg}^{2+}$ & $10^{21.8}$ & $\begin{array}{c}\text { Quicksilver, } \\
\mathrm{HgCl}_{2}\end{array}$ & 0.01 & $\begin{array}{c}\text { Nerve, brain, } \\
\text { liver }\end{array}$ & 25 \\
\hline 4 & $\mathrm{Mo}^{4+}$ & $10^{20}$ & $\mathrm{MoS}_{2}$ & 0.031 & $\begin{array}{l}\text { Anemia, } \\
\text { arthritis }\end{array}$ & 26 \\
\hline 5 & $\operatorname{In}^{3+}$ & $10^{25.8}$ & ITO, InP & 3.6 & Cancer, kidney & 27 \\
\hline 6 & $\mathrm{Mn}^{2,3,4+}$ & $10^{27}$ & $\mathrm{MnOx}$ & 0.015 & Nerve, lung & 28 \\
\hline 7 & $\mathrm{Sn}^{4+}$ & $10^{34.5}$ & $\mathrm{SnO}_{2}$ & 5 & $\begin{array}{c}\text { Nerve, liver, } \\
\text { skin }\end{array}$ & 29 \\
\hline 8 & $\mathrm{Zn}^{2+}$ & $10^{16.5}$ & $\mathrm{ZnO}, \mathrm{ZnS}$ & 130 & $\begin{array}{c}\text { Anemia, heart, } \\
\text { hypertension }\end{array}$ & 30 \\
\hline 9 & $\mathrm{Bi}^{3+}$ & $10^{27.9}$ & $\begin{array}{l}\mathrm{Bi}_{2} \mathrm{O}_{3}, \\
\mathrm{Bi}_{2} \mathrm{Se}_{3}\end{array}$ & 0.05 & Nerve & 30 \\
\hline 10 & $\mathrm{Cu}^{2+}$ & $10^{18.8}$ & $\mathrm{CuO}, \mathrm{Cu}_{2} \mathrm{O}$ & 140 & $\begin{array}{l}\text { Liver, kidney, } \\
\text { skin }\end{array}$ & 30 \\
\hline
\end{tabular}

Data availability: All data are available from the corresponding author(s) upon reasonable request.

Acknowledgments: None. 
Competing interests: The authors declare no competing financial interest

\section{References}

1. https://www.nrel.gov/pv/cell-efficiency.html, Best Research-Cell Efficiencies, National Renewable Energy Laboratory, accessed: 7, 2020.

2. Lin K, Xing J, Quan L N, et al. Perovskite light-emitting diodes with external quantum efficiency exceeding 20 percent[J]. Nature, 2018, 562(7726): 245-248.

3. Cao Y, Wang N, Tian H, et al. Perovskite light-emitting diodes based on spontaneously formed submicrometre-scale structures[J]. Nature, 2018, 562(7726): 249-253.

4. Yang Z, Deng Y, Zhang X, et al. High-Performance Single-Crystalline Perovskite ThinFilm Photodetector[J]. Advanced Materials, 2018, 30(8): 1704333.

5. Deng Y H, Yang Z Q, Ma R M. Growth of centimeter-scale perovskite single-crystalline thin film via surface engineering[J]. Nano convergence, 2020, 7(1): 1-7.

6. Zhu H, Fu Y, Meng F, et al. Lead halide perovskite nanowire lasers with low lasing thresholds and high quality factors[J]. Nature materials, 2015, 14(6): 636-642.

7. Ara A, Usmani J A. Lead toxicity: a review[J]. Interdisciplinary toxicology, 2015, 8(2): 5564.

8. Sanders T, Liu Y, Buchner V, et al. Neurotoxic effects and biomarkers of lead exposure: a review[J]. Reviews on environmental health, 2009, 24(1): 15.

9. Plog, B. A.; Quinlan, P. J. Fundamentals of Industrial Hygiene, 6th ed.; Plog, B. A., Quinlan, P. J., Eds.; National Safety Council: 2012.

10. Tchounwou P B, Yedjou C G, Patlolla A K, et al. Heavy metal toxicity and the environment[M]//Molecular, clinical and environmental toxicology. Springer, Basel, 2012: $133-164$.

11. Babayigit A, Ethirajan A, Muller M, et al. Toxicity of organometal halide perovskite solar cells[J]. Nature materials, 2016, 15(3): 247.

12. World health organization (WHO), Lead poisoning and health, 2019. Available online at: https://www.who.int/news-room/fact-sheets/detail/lead-poisoning-and-health (accessed September 2, 2020).

13. Salvador M, Motter C E, McCulloch I. The hidden perils of lead in the lab: Guidelines for 
containing, monitoring and decontaminating lead in the context of perovskite research[J]. Chemistry of Materials, 2020.

14. Flora G, Gupta D, Tiwari A. Toxicity of lead: a review with recent updates[J]. Interdisciplinary toxicology, 2012, 5(2): 47-58.

15. Hsu P C, Guo Y L. Antioxidant nutrients and lead toxicity[J]. Toxicology, 2002, 180(1): $33-44$.

16. Huang Y, Keller A A. EDTA functionalized magnetic nanoparticle sorbents for cadmium and lead contaminated water treatment[J]. Water research, 2015, 80: 159-168.

17. Sears M E. Chelation: harnessing and enhancing heavy metal detoxification —a review[J]. The Scientific World Journal, 2013, 2013.

18. Furia, T. (1964). "EDTA in Foods - A technical review". Food Technology. 18 (12): 18741882.

19. Wong M H. Ecological restoration of mine degraded soils, with emphasis on metal contaminated soils[J]. Chemosphere, 2003, 50(6): 775-780.

20. Pozdniakova S, Ragauskas R, Dikčius A, et al. Determination of EDTA in used fixing solutions by capillary electrophoresis[J]. Fresenius' journal of analytical chemistry, 1999, 363(1): 124-125.

21. Gardziella A, Pilato L A, Knop A. Phenolic resins: chemistry, applications, standardization, safety and ecology[M]. Springer Science \& Business Media, 2013.

22. Nur Y, Rohaeti E, Darusman L K. Optical Sensor for the Determination of Lead (II) Based On Immobilization of Dithizone onto Chitosan-Silica Membrane[J]. Indonesian Journal of Chemistry, 2017, 17(1): 7-14.

23. Butts P G, Gahler A R, Mellon M G. Colorimetric determination of metals in sewage and industrial wastes[J]. Sewage and Industrial Wastes, 1950: 1543-1562.

24. Kah M, Levy L, Brown C. Potential for effects of land contamination on human health. 1. The case of cadmium[J]. Journal of Toxicology and Environmental Health, Part B, 2012, 15(5): 348-363.

25. Ye B J, Kim B G, Jeon M J, et al. Evaluation of mercury exposure level, clinical diagnosis and treatment for mercury intoxication[J]. Annals of Occupational and Environmental Medicine, 2016, 28(1). 
26. SCF (Scientific Committee on Food). Opinion on the Tolerable Upper Intake Level of molybdenum[J]. 2000.

27. Castronovo F P, Wagner H N. Factors affecting the toxicity of the element indium[J]. British journal of experimental pathology, 1971, 52(5): 543.

28. Williams M, Todd G D, Roney N, et al. Toxicological profile for manganese[J]. 2012.

29. Howe P, Watts P. Tin and inorganic tin compounds[M]. World health organization, 2005.

30. Goyer R A, Clarkson T W. Toxic effects of metals[J]. Casarett and Doull's toxicology: the basic science of poisons, 1996, 5: 696-8.

31. Rong Y, Hu Y, Mei A, et al. Challenges for commercializing perovskite solar cells[J]. Science, 2018, 361(6408).

\section{Table of Contents text}

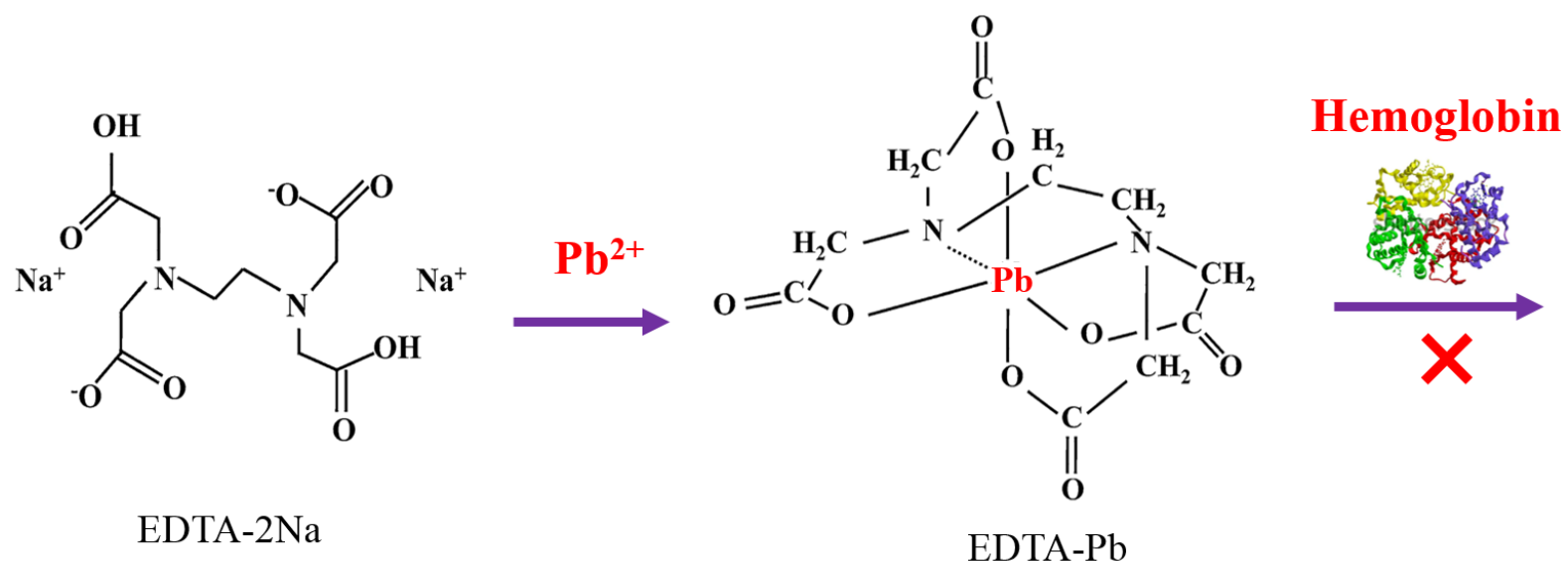

Graphical Abstract: An operable method to treat lead sources with low-cost and eco-friendly chelating agent (EDTA-2Na), which paves the way to protect the health of researchers in lead halide perovskite laboratory. 